\title{
Dampak Penerapan Rantai Pasokan Berkelanjutan Terhadap Keunggulan Kompetitif Pada UMKM Konveksi di Desa Nogotirto
}

\section{Maisaroh}

Program Studi Manajemen Program Diploma Tiga, Fakultas Bisnis dan Ekonomi, Universitas Islam Indonesia

Jl. Kaliurang No.Km. 14,5, Krawitan, Umbulmartani, Sleman, Daerah Istimewa Yogyakarta 55584, Jawa Tengah, Indonesia

maisaroh@uii.ac.id

\begin{tabular}{l} 
INFO ARTIKEL \\
\hline Jejak Artikel : \\
Upload artikel \\
O2 Maret 2021 \\
Revisi \\
O9 September 2021 \\
Publish \\
30 September 2021 \\
\\
Kata Kunci : \\
Manajemen rantai pasokan \\
berkelanjutan, \\
manajemen rantai pasokan, \\
keunggulan kompetitif
\end{tabular}

ABSTRAK

Penelitian ini adalah penelitian kualitatif deskriptif, untuk menganalisis bagaimana pola dan penerapan manajemen rantai pasokan berkelanjutan, dan dampaknya terhadap pencapaian keunggulan kompetitif industri konveksi di Dusun Mlangi Sawahan Nogotirto. Data penelitian dikumpulkan dari observasi dan wawancara terhadap para pelaku yang terlibat dalam manajemen rantai pasokan industri konveksi di Desa Sawahan Nogotirto, Hasil penelitian menunjukkan bahwa 1.) Pola manajemen rantai pasokan yang terbangun pada industri konveksi di Mlangi Sawahan Nogotirto melibatkan supplier utama, supplier perantara, industri konveksi, pedagang besar dan eceran, serta konsumen akhir. 2.) Praktek manajemen rantai pasokan pada industry konveksi di Mlangi Sawahan Nogotirto sudah terintegrasi dari hulu ke hilir. 3.) Industri konveksi di Nogotirto juga sudah menerapkan manajemen rantai pasokan berkelanjutan dan berdampak positif terhadap keunggulan kompetitif, 4 . Keunggulan kompetitif ditunjukkan dengan kualitas produk yang lebih baik serta faktor kedekatan dengan lokasi pasar. Keterbatasan penelitian ini adalah masih sedikitnya responden yang terlibat dalam penelitian. 


\section{Pendahuluan}

Manajemen rantai pasokan adalah salah satu sistem terintegrasi yang menghubungkan seluruh lingkup bisnis baik internal maupun eksternal. Dalam manajemen rantai pasokan terhubung pihakpihak yang terkait dalam satu industri dari hulu ke hilir dalam kegiatan yang berbeda, untuk menciptakan nilai baik barang maupun jasa bagi konsumen akhir. Proses manajemen rantai pasokan memungkinkan masing-masing pihak yang ada didalamnya membuat koordinasi yang terintegrasi, sehingga menciptakan efisiensi dan efektifitas kerjamasing-masing pelakunya. Efektifitas dan efisiensi kerja ini yang akan menjadi modal utama membangun keunggulan kompetitif perusahaan.

Selain membangun keunggulan kompetitif, manajemen rantai pasokan juga membawa dampak pada pola persaingan. Saat ini pola persaingan antar pelaku industri bukan lagi face to face antara satu industri dengan industri lain dalam bidang yang sama, akan tetapi persaingannya bergeser menjadi persaingan antar rantai pasokan yang ada dalamindustri. Kesadaran untuk berkolaborasi dalam penerapan manajemen rantai pasokan menjadi strategi yang dibangun untuk memenangkan persaingan. Berkaitan dengan isu lingkungan, maka manajemen rantai pasokan yang kuat dan baik mensyaratkan integrasi dan berkelanjutan [1]. Proses manajemen rantai pasokan terintegrasi akan menuju pada manajemen rantai pasokan yang terintegrasi, yang akan memberikan dampak positif pada pengurangan resiko lingkungan, sehingga akan menaikkan performa organisasi [2] [3].

Penelitian tentang penerapan manajemen rantai pasokan di perusahaan membuktikan bahwa praktek manajemen rantai pasokan akan mempengaruhi kinerja perusahaan [2]. Begitu juga penerapan rantai pasokan juga akan berdampak pada penciptaan keunggulan kompetitif dan persaingan diantara pelaku industry [3]. Disisi lain, publikasi dibidang manajemen rantai pasokan berkelanjutan di Indonesia masih cukup rendah, bila dibandingkan dengan negara lain [4]. Manajemen rantai pasokan berkelanjutan menghasilkan pola dan dampak yang berbeda-beda untuk beberapa kategori industry. Penelitian tentang pola manajemen rantai pasokan berkelanjutan di industry furnitur [1], Batubara, et all (2017) meneliti pola manajemen rantai pasokan berkelanjutan pada industry perikanan tangkap [5]. Yekti dan Solovida (2021) dalam penelitiannya terkait manajemen rantai pasokan berkelanjutan pada perusahaan di Jawa Tengah membuktikan bahwa praktek manajemen rantai pasokan berkelanjutan secara langsung tidak memberikan dampak positif pada kinerja perusahaan, pengaruhnya muncul karena ada variabel lain yang mempengaruhi yaitu entrepreneurial dan capital social strategy [8].

Saat ini ada 57 UMKM konveksi yang terdaftar di pedukuhan Mlangi Sawahan Nogotirto. Sentra industri konveksi ini setiap hari memproduksi produk pakaian jadi dengan pangsa pasar adalah para pelancong yang sedang berwisata di Jogjakarta dan sebagian Jawa Tengah. Operasional UMKM sehari-hari dijalankan dengan konsep tradisional, dikelola secara individu dan kekeluargaan, serta manajemen yang sangat sederhana. Meskipun demikian beberapa UMKM dengan skala menengah sudah memiliki omset dalam skala milyar per tahun [6]. Berdasarkan observasi awal yang dilakukan peneliti, tantangan terbesar yang dihadapi dalam penerapan manajemen rantai pasokan di wilayah ini adalah masih kurangnya kesadaran dan pengetahuan di antara pihak yang terlibat dalam rantai pasokan. Sehingga kondisi ini berimbas pada masih kurangnya integrasi yang terbangun diantara pihak-pihak yang terlibat dalam rantai pasokan, terutama dalam hal penyampaian informasi. Kurangnya integrasi informasi ini menjadikan kinerja rantai pasokan tidak optimal.

Penelitian ini bertujuan untuk untuk menganalisis pola dan penerapan manajemen rantai pasokan industri konveksi serta dukungannya terhadap rantai pasokan terintegrasi dan berkelanjutan di Kelurahan Nogotirto. Untuk melihat dampak dari penerapan manajemen rantai pasokan, akan dihubungkan pencapaian keunggulan kompetitif industri konveksi di Kelurahan Nogotirto.

\section{Literatur}

\section{Manajemen Rantai Pasokan}

Supply chain atau dapat diterjemahkan "rantai pasok " adalah rangkaian hubungan antar perusahaan atau aktivitas yang melaksanakan penyaluran pasokan barang atau 
MATRIK: Jurnal Manajemen \& Teknik Industri - Produksi Volume XXII, No.1, September 2021, Halaman 85- 94 jasa dari tempat asal sampai ke tempat pembeli atau pelanggan [7]. Supply chain menyangkut hubungan yang terus-menerus mengenai barang, uang dan informasi. Barang umumnya mengalir dari hulu ke hilir, begitu pun uang mengalir dari hilir ke hulu, sedangkan informasi mengalir baik dari hulu ke hilir maupun hilir ke hulu. Rantai pasokan (supply chain) adalah segala aktivitas yang terintegrasi ter masuk didalamnya juga aliran informasi yang berkaitan dengan tiga aspek, yaitu sumber, proses produksi, dan proses penghantaran produk [8]. Dilihat secara horizontal, ada lima komponen utama atau pelaku dalam supply chain, yaitu supplier (pemasok), manufacturer (pabrik pembuat barang), distributor (pedagang besar), retailer (pengecer), customer (pelanggan). Secara Vertikal, ada lima komponen utama supply chain, yaitu buyer (pembeli), transpoter (pengangkut), warehouse (penyimpan), seller (penjual) dan sebagainya [7].

Manajemen rantai pasokan sebagai manajemen dari jaringan bisnis mulai dari awal produksi sampai kepada pemenuhan permintaaan barang-barang dan jasa yang diinginkan konsumen akhir [9]. Konsep manajemen rantai pasok merujuk pada manajemen keseluruhan proses produksi, distribusi, dan pemasaran di mana konsumen dihadapkan pada produk yang sesuai dengan keinginannya dan produsen dapatmemproduksi produk dengan jumlah, kualitas, waktu, dan lokasi yang tepat [10]. Kajian manajemen rantai pasok meliputi hal yang sangat luas, mulai dari titik awal sebelum proses produksi, proses produksi, proses inventori dan distribusi, sampai kepada titik akhir konsumen.

Dalam persektif yang berbeda
manajemen rantai pasok sekumpulan aktivitas dan keputusan yang saling tekait untuk mengintegrasikan pemasok, manufaktur, gudang, jasa transportasi, pengecer, dan konsumen secara efisien [11]. Manajemen rantai pasok adalah integrasi aktivitas pengadaan bahan baku dan pelayanan, pengubahan barang setengah jadidan produk akhir, serta pengiriman ke pelanggan [12]. Dengan demikian, manajemen rantai pasok meliputi seluruh aktivitas yang mencakup pembelian dan pengubahan bentuk barang atau produk, serta fungsi pelayanan yang penting bagi
p-ISSN: 1693-5128, e-ISSN : 2621-8933 doi: $10.350587 /$ Matrik v22i1.2382

keseluruhan hubungan pemasok (supplier) dan distributor untuk memenuhi kebutuhan pelanggan.

\section{Manajemen Rantai Pasokan Terintegrasi}

Manajemen rantai pasokan merupakan integrasi dari beberapa proses bisnis inti melalui original supplier (pemasok awal) menuju end user (konsumen akhir) yang menyediakan barang, jasa dan informasi yang mampu memberikan tambahan nilai bagi konsumen. Terdapat tiga level struktur integrasi di dalam supply chain. Pertama, level fungsional yaitu integrasi dalam beberapa fungsi perusahaan. Misalnya integrasi dalam fungsi pembelian, persediaan atau pemasaran. Kedua, level internal yaitu integrasi di dalam berbagai fungsi perusahaan yang bertujuan agar internal perusahaan dapat menghasilkan produk ataujasa secara efisien. Ketiga, level eksternal yaitu integrasi perusahaan baik kepada pemasok maupun konsumen agar aliran bahan mentah mengalir secara lancar dan produk jadi dapat dikonsumsi konsumen pada kualitas, waktu, jumlah dan lokasi yang diharapkan [13] [14] [15]. Pernyatakan bahwa dalam rantai pasok yang terintegrasi terdapat proses-proses berikut ini [15]:

1. Strategic Supplier Partnership, yang didefinisikan sebagai hubungan jangka panjang antara perusahaan dengan suppliernya. Strategi ini lebih berfokus untuk melakukan perencanaan bersama (mutual planning) dan melakukan upaya pemecahan masalah bersama antara perusahaan dan supplier [16].

2. Customer Relationship, yang bertujuan untuk mengelolah keluhan pelanggan, membangun hubungan jangka panjang yang baik dengan pelanggan, dan meningkatkan kepuasan pelanggan.

3. Information Sharing, yang mengacu pada sejauh mana informasi penting dikomunikasikan terhadap mitra usaha perusahaan [17].

Aktifitas manajemen rantai pasokan terintegrasi terkandung tiga aktifitas sekaligus yang saling berhubungan, yaitu aliran produk, aliran dana, dan aliran informasi dari hulu ke hilir, baik aspek sumber bahan mentah, proses produksi, maupun aspek distribusi produk. Secara teori, seharusnya, manajemen rantai pasokan terintegrasi untuk aliran produk terbangun dari hulu ke hilir, untuk aliran dana 
terbangun dari hilir ke hulu, sementara aliran informasi terbangun dari dua arah, yaitu hulu kehilir dan dari hilir ke hulu.

Secara nyata manajemen rantai pasokan terintegrasi akan memberikan dampak pada keunggulan kompetitif dalam manajemen kepemimpinan dan keunggulan teknologi yang dicapai perusahaan [21], manajemen kualitas [22], serta performa bisnis perusahaan [22] [21] [23] [2] [3].

\section{Manajemen Rantai Pasokan Berkelanjutan}

Manajemen rantai pasokan berkelanjutan merupakan manajemen rantai pasok yang mengintegrasikan rantai pasokan dalam tiga aspek sekaligus, yaitu aspek ekonomi, sosial, dan lingkungan untuk membangun kualitas produk dan kualitas pelayanan yang diberikan sesuai dengan harapan konsumen [18] [19]. Selain menggunakan ketiga aspek di atas, manajemen rantai pasokan berkelanjutan dapat dijelaskan dengan menggunakan tiga dimensi organisasi berkelanjutan, yaitu inbound sustainability, internal sustainability, dan outbound sustainability [23]. Manajemen rantai pasokan berkelanjutan disinyalir dapat memberikan manfaat terhadap ketiga aspek berkelanjutan. Begitu juga penerapan manajemen rantai pasokan berkelanjutan dapat mengoptimalkan kinerja rantai pasokan. Manajemen rantai pasokan berkelanjutan memberikan dampak yang besar pada strategi total quality management yang dilakukan perusahaan, dan akan berimbas pada kinerja bisnis perusahaan [24].

\section{Keunggulan Kompetitif}

Keunggulan bersaing pada dasarnya tumbuh dari nilai atau manfaat yang dapat diciptakan perusahaan bagi para pembelinya yang lebih dari biaya yang harus dikeluarkan perusahaan untuk menciptakannya. Nilai atau manfaat inilah yang bersedia dibayar oleh pembeli, dan nilai yang unggul berasal dari penawaran harga yang lebih rendah ketimbang harga pesaing untuk manfaat setara atau penawaran manfaat unik yang melebihi harga yang ditawarkan [20]. Keunggulan bersaing adalah keunggulan terhadap pesaing yang diperoleh dengan menawarkan nilai lebih rendah maupun dengan memberikan manfaat lebih besar karena harganya lebih tinggi [21].

\section{Manajemen Rantai Pasokan dan Kinerja Perusahaan}

Manajemen rantai pasokan sangat berhubungan erat dengan analisis rantai nilai. Terdapat hubungan saling melengkapi antara konsep manajemen rantai pasok dengan analisis rantai nilai. Analisis rantai nilai adalah kegiatan lengkap yang diawali dari perumusan konsep, kegiatan produksi, mengirimkan ke pelanggan melalui pedagang, pengolah, dan distributor; hingga ke konsumen akhir, sehingga perusahaan memiliki keunggulan kompetitif [22]. Secara ringkas dapat dikatakan bahwa rantai nilai adalah seluruh kegiatan yang membentuk keseluruhan 'rantai' yang menghubungkan produsen dengan konsumen, dan tiap kegiatan menambahkan 'nilai' pada produk akhir [23]. Terdapat tiga tahapan dalam analisis rantai nilai, yaitu pertama, mengidentifikasi aktivitas rantai nilai, di mana produsen atau perusahaan pengolah mengidentifikasi aktivitas rantai nilai yang harus dilakukan, mungkin hanya terlibat dalam aktivitas tunggal, sebagian dari aktivitas, atau aktivitas keseluruhan. Kedua, mengidentifikasi faktor kunci sukses pada setiap aktivitas yang menciptakan nilai yang akan menjadi penentudalam proses rantai nilai tersebut. Dan ketiga mengembangkan keunggulan kompetitif dengan upgrading, baik dalam bentuk process upgrading, functional upgrading, dan chain upgrading [24].

Indikator dari kinerja manajemen rantai pasok mencakup pengembangan produk, kemitraan strategis dengan pemasok, perencanaan dan pengendalian, produksi, distribusi, kualitas informasi, customer relationship, dan pembelian. Penerapan manajemen rantai pasok berpengaruh positif dan signifikan terhadap keunggulan bersaing. Hasil analisis selanjutnya menunjukkan bahwa penerapan manajemen rantai pasok berpengaruh positif dan signifikanterhadap kinerja perusahaan yang direfleksikan oleh tingkat produktivitas, pertumbuhan penjualan, serta pangsa pasar. Kinerja perusahaan merupakan standar ukurkeberhasilan suatu perusahaan dalam mengelola operasinya. Untuk mengukur kinerja suatu rantai pasokan, model SCOR (Supply chain Operation Reference Model) [2]. SCOR menampilkan suatu cara standarisasi pengukuran kinerja rantai pasokan.

Ada beberapa indikator yang dapat digunakan untuk mengukur keunggulan bersaing 
suatu perusahaan. Mengukur keunggulan bersaing perusahaan dengan menggunakan indikator; harga, kualitas, delivery dependability, inovasi produk, dan time to market [15]. Keberhasilan perusahaan diukur melalui pencapaian keunggulan kompetitif melalui perolehan value advantage dan productivity advantage [13]. Sumber keunggulan kompetitif tersebutterletak pada dua hal yaitu: Kemampuan perusahaan melayani konsumen yang dapat membedakan diri dari para pesaingnya yang disebut manfaat nilai (value advantage) [25]. Faktoryang sangat penting dalam memperoleh manfaat nilai adalah memberikan pelayanan yang sebaik-baiknya. Indikator manfaat nilai pelayanan terhadap pelanggan (customer service), kepuasan pelanggan (customer satisfaction), kesesuaian kualitas (conformance quality), keragaman produk, pengiriman tepat Waktu [13]. Indikator manfaat produktifitas adalah kemampuan perusahaan untuk beroperasi secara efesien dan efektif, yang meliputi keuntungan yang lebih tinggi, kenaikan pangsa pasar, penurunan biaya tenaga kerja [25]. Indikator lainnya biaya total overhead dan bahan baku rendah, lead time proses pendek, lead time pembelian pendek, lead time pengiriman pendek, pengiriman tepat waktu dan inventori turn over tinggi [13].

\section{Metode Penelitian}

Penelitian ini adalah penelitian kualitatif deskriptif untuk menggali data terkait dengan penerapan manajemen rantai pasokan sentra industri konveksi di Desa Nogotirto. Data penilitian yang digunakan merupakan data primer dan data sekunder, yang dikumpulkan melalui observasi proses bisnis dan penerapan manajemen rantai pasokan, wawancara mendalam terhadap pelaku rantai pasokan, dan studi pustaka. Responden yang dipilih dalam penelitian berjumlah 10 orang, terdiri dari 6 pimpinan UMKM, 2 responden dari pihak supplier, dan 2 responden mewakili konsumen.

Untuk mengetahui keabsahan data (apakah proses dan hasil penelitian dapat dipercaya atau tidak) maka peneliti menggunakan metode triangulasi, menggunakan beberapa responden yang berbeda untuk mengkonfirmasi keabsahan data dari responden utama, juga menggunakan konsep teori sebagai pembanding.

Analisis data dilakukan secara deskriptif kualitatif untuk menjawab pertanyaanpertanyaan yang disajikan dalam penelitian.

\section{Hasil dan Pembahasan Profile Umum}

Dusun Sawahan dan Mlangi, adalah salah satu sentra industry konveksi yang ada diKelurahan Nogotirto Gamping Sleman Yogyakarta. Berdasarkan Penelitian Maisaroh (2019) disebutkan bahwa, jumlah industry konveksi di wilayah tersebut ada 56 usaha. Secara rinci data industri dapat disajikan dalam tabel berikut [26] :

Tabel 1

Data UMKM

\begin{tabular}{|l|l|}
\hline \multicolumn{1}{|c|}{ Kategori } & \multicolumn{1}{c|}{ Jumlah } \\
\hline Usaha Menengah & 6 \\
\hline Usaha Kecil dan Mikro & 50 \\
\hline
\end{tabular}

Secara lengkap profil usaha ditampilkan dalam tabel berikut

Tabel 2

Profil UMKM

\begin{tabular}{|l|l|}
\hline Faktor & Kondisi UMKM \\
\hline Produk & Baju Konveksi \\
\hline Bahan Baku & $\begin{array}{l}\text { Jumputan dan batik } \\
\text { printing }\end{array}$ \\
\hline Serapan Tenaga Kerja & 7-15 Karyawan \\
\hline Pasar & $\begin{array}{l}\text { Malioboro dan Pasar } \\
\text { Beringharjo }\end{array}$ \\
\hline
\end{tabular}

\section{Praktik Manajemen Rantai Pasokan Terintegrasi}

Manajemen rantai pasokan terintegrasi, selalu mengintegrasikan aliran produk, dana, dan aliran komunikasi dalam satu sistem yang terintegrasi. Secara umum praktik manajemen rantai pasokan industri konveksi di Dusun Mlangi Sawahan Nogotirto, terlihat pada gambar 1.

Gambar menjelaskan praktik manajemen rantai pasokan. Dari gambar satu bisa dilihat bahwa pelaku utama maanjemen rantai masokan terdiri dari supplier utama, supplier perantara, industry konveksi itu sendiri, pedagang besar/ecer, dan terakhir konsumen akhir. Masing-masing memiliki peran yang berkaitan satu sama lain. Supplier utama berperan sebagai penyedia bahan baku mentah produk konveksi. Pelaku industri dalam kategori ini adalahpabrik/perusahaan tekstil yang berlokasi di solo dan Jogja. Supplier perantara, bertindak sebagaiperantara penyedia bahan baku mentah produk konveksi dari supplier utama ke perusahaan industri konveksi. Pelaku industri dalam kategori ini adalah pengusaha penyedia bahan baku mentah diMlangi Sawahan Nogotirto.

Industri Konveksi, yaitu usaha kecil menengah yang memproduksi produk konveksi. 
Pelaku industri dalam kategori ini ada 56 UMKM. Pedagang pengecer, bertindak sebagai agen penjual produk konveksi kepada konsumen akhir. Pelaku industri dalam kategori ini adalah pedagang kaki lima di lokasi wisata Malioboro dan pedagang pasar beringharjo. Terakhir, konsumen akhir, adalah pembeli akhir produk konveksi, yang terdiri dari wisatawan baik lokal, nasional, maupunmanca negara yang membeli dalam jumlah/partai besar maupun membeli dalam jumlah kecil (eceran).

Pola aliran manajemen rantai pasokan menjelaskan bagaimana aliran produk, aliran dana, dan aliran informasi terjadi dalam praktik manajemen rantai pasokan. Ada dua pola aliran produk manajemen rantai pasokan yang terbangun pada industri konveksi Mlangi Sawahan Nogotirto.

1. Supplier utama - supplier perantara industri konveksi - pedagang besar/pengecer - konsumen akhir

2. Supplier utama - industri konveksi pedagang besar/pengecer - konsumen akhir.

Aliran dana pada manajemen rantai pasokan mengalir dari hilir ke hulu, dimana konsumen membeli produk dari pengecer, kemudian pengecer membelanjakan hasil penjualan untuk membeli kembali produk yang sudah habis stoknya ke industri konveksi, dan terakhir industri konveksi akan membelanjakan hasil penjualannya untuk membeli bahan mentah ke supplier perantara/supplier utama. Sebagai ilustrasi, untuk satu produk konveksi daster, konsumen membeli dari pengecer seharga $\mathrm{Rp} 35.000$, kemudian pengecer membeli daster dari industry seharga $\mathrm{Rp}$ 27.500, kemudian industry membeli bahan mentah batik printing seharga Rp 22.000 ( untuk ukuran satu daster) di tingkat supplier perantara, atau Rp 20.000 di tingkat supplier utama.

Proses terakhir adalah aliran informasi, dimana pola aliran informasi yang terjadi dalam manajemen rantai pasokan merupakan aliran informasi dua arah, yaitu dari hulu ke hilir dan sebaliknya dari hilir ke hulu. Informasi darihilir ke hulu biasanya terkait dengan harga pasar, spesifikasi model yang disukaikonsumen, dan jumlah permintaan konsumen. Sedang informasi dari hulu ke hilir, terkait dengan negosiasi harga, model yang sedangdiproduksi, serta jumlah persediaan yang tersedia.

Satu hal yang perlu dicatat, dari hasil interview menunjukkan bahwa proses manajemen rantai pasokan yang selama ini dibangun, masih berkutat untuk mencapai tujuan jangka pendek, yaitu agar target penjualan dan keuntungan terpenuhi. Perencanaan strategis untuk inovasi produk yang melibatkan seluruh pelaku belum terealisasikan. Begitupun perencanaan terkait dengan membangun nilai pelanggan dan penanganan keluhan pelanggan juga belum dilakukan.

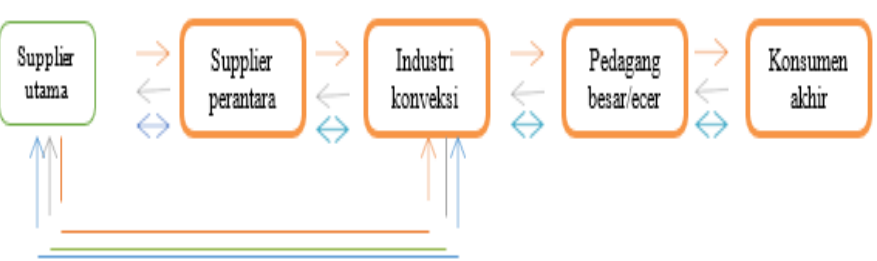

Gambar 1. Pola Manajemen Rantai Pasokan Terintegrasi

\section{Manajemen Rantai Pasokan Berkelanjutan}

Manajemen rantai pasokan berkelanjutan merupakan penerapan yang terintegrasi proses rantai pasokan, yang memasukkan aspek ekonomi, sosial, dan lingkungan dalam jangka panjang. Secara ringkas hasil penelitian terkait dengan praktek manajemen rantai pasokan berkelanjutan akan ditampilkan dalam tabel berikut ini,

\section{Tabel 3}

Rangkuman

Praktik Manajemen Rantai Pasokan Berkelanjutan

\begin{tabular}{|c|c|c|}
\hline Aspek & Indikator & $\begin{array}{l}\text { Paparan di } \\
\text { lapangan }\end{array}$ \\
\hline \multirow[t]{4}{*}{ Ekonomi } & Efisiensi biaya & $\begin{array}{l}\text { Efisiensi } \\
\text { penggunaan } \\
\text { bahan baku dan } \\
\text { ongkos } \\
\text { produksi menjadi } \\
\text { lebih murah, dan } \\
\text { melakukan } \\
\text { kegiatan pemasaran } \\
\text { sendiri. }\end{array}$ \\
\hline & Kualitas & Belum tercapai \\
\hline & Responsiveness & $\begin{array}{l}\text { Selalu merespon } \\
\text { dengan cepat } \\
\text { setiap permintaan } \\
\text { konsumen, dalam } \\
\text { hal ini pedagang } \\
\text { besar atau eceran }\end{array}$ \\
\hline & $\begin{array}{l}\text { Kenaikan } \\
\text { penjualan }\end{array}$ & Belum tercapai \\
\hline Sosial & $\begin{array}{l}\text { Kepuasan } \\
\text { konsumen }\end{array}$ & $\begin{array}{l}\text { Parameter } \\
\text { pembelian yang } \\
\text { berulang, dan } \\
\text { dominasi produk } \\
\text { di beberapa } \\
\text { wilayah } \\
\end{array}$ \\
\hline
\end{tabular}


MATRIK: Jurnal Manajemen \& Teknik Industri - Produksi Volume XXII, No.1, September 2021, Halaman 85- 94

\begin{tabular}{|c|c|c|}
\hline & & penjualan \\
\hline & $\begin{array}{l}\text { Kesejahteraan } \\
\text { karyawan }\end{array}$ & Belum tercapai \\
\hline \multirow[t]{2}{*}{ Lingkungan } & $\begin{array}{l}\text { Penggunaan } \\
\text { bahan baku }\end{array}$ & $\begin{array}{l}\text { Efisiensi } \\
\text { penggunaan } \\
\text { bahan baku, dan } \\
\text { pemanfaatan } \\
\text { limbah } \\
\text { bahan menjadi } \\
\text { lebih bernilai } \\
\text { ekonomis }\end{array}$ \\
\hline & $\begin{array}{l}\text { Kontribusi } \\
\text { pada } \\
\text { lingkungan }\end{array}$ & $\begin{array}{l}\text { Penyerapan } \\
\text { tenaga kerja } \\
\text { sekitar }\end{array}$ \\
\hline
\end{tabular}

Ada 4 indikator yang digunakan untuk menganalisis capaian berkelanjutan dari aspek ekonomi, yaitu efisiensi biaya, kualias produk, responsiveness, dan kenaikan penjualan, yang bermuara pada kenaikan pendapatan dari waktu ke waktu. Dari tabel dapat dijelaskan, industri konveksi di Dusun Mlangi Sawahan Nogotirto sudah menuju pada pola efisiensi biaya, yang dibangun dari efisiensi penggunaan bahan baku produksi, ongkos produksi yang lebih murah, dan biaya pemasaran yang lebih murah. Ongkos produksi dan biaya pemasaran yang lebih murah terjadi karena beberapa proses produksi dan kegiatan pemasaran dilakukan sendiri oleh pemilik usaha.

Indikator responsiveness terlihat dari upaya pelaku industri untuk merespon dengan cepat setiap permintaan dari konsumen pedagang besar dan eceran. Bahkan mereka membuat produk berdasarkan permintaan dan pesanan.

Indikator kualitas, dan kenaikan penjualan masih belum tercapai secara maksimal. Kualitas produk masih menjadi persoalan utama dari kelompok industri ini. Hal ini karena ditingkat konsumen, image produk konveksi rata-rata berkualitas rendah, dan harga murah. Karena image tersebut sampai saat ini industri konveksi dalam memproduksi tidak pernah memperhatikan kualitas produk.

Indikator yang dianalisis pada aspek sosial adalah kepuasan konsumen dan kesejahteraan karyawan. Indikator kepuasan konsumen sebenarnya bisa dilihat dari banyak sudut pandang. Yang paling mudah ukuran kepuasan konsumen adalah loyalitas konsumen untuk melakukan proses pembelian kembali. Di kawasan pedagang kaki lima Malioboro, produk konveksi yang dijual di wilayah ini didominasi oleh produk konveksi dari industri konveksi Dusun Mlangi Sawahan Nogotirto. Kondisi ini bisa menjadi parameter ukuran kepuasan konsumen pedagang besar/ecerandalam berbelanja di industri konveksi Dusun Mlangi Sawahan Nogotirto. Akan tetapi jika ditinjau dari sisi konsumen akhir, belum ada data yang pasti apakah konsumen akhir puas dengan produk konveksi dari Dusun MlangiSawahan Nogotirto. Sampai saat ini belum ada pelaku industri yang mencoba membangun kepuasan dari sudut konsumen akhir secara langsung, karena bagi mereka konsumen mereka adalah pedagang besar atau eceran.

Aspek sosial yang terakhir adalah indikator kesejahteraan karyawan masih belum terwujud. Sampai saat ini hampir seluruh pelaku industri konveksi di wilayah Dusun Mlangi Sawahan Nogotirto mempekerjakan karyawan lepas yang bekerja berdasarkan pesanan. Mereka dibayar dengan upah yang masih dibawah standar UMR dan dibayar berdasarkan jumlah produksi. Mereka tidak diberikan bonus dan gaji tambahan. Karena kesejahteraan karyawan yang masih minim tersebut, mereka menjadi tidak loyal, dan tingkat turn overnya tinggi [6].

Aspek lingkungan dianalisis menggunakan indikator penggunaan bahan baku ramah lingkungan dan kontribusi terhadap lingkungan sekitar. Untuk penggunaan bahan baku ramah lingkungan, upaya yang dilakukan oleh pelaku industri masih sebatas penggunaan bahan yang seefisien mungkin, sehingga tidak banyak sampah bahan yang terbuang. Begitu juga kalau ada sisa bahan, mereka akan menjualnya kepada industri produk kain perca, atau dibagikan kepada masyarakat yang membutuhkan. Untuk Bahan ramah lingkungan masih belum bisa mereka wujudkan, mengingat produk yang mereka jual adalah produk konveksi dengan harga murah, sementara untuk bahan ramah lingkungan harganya mahal dan tidak masuk untuk produk konveksi. Kontribusi terhadap lingkungan terwujud dalam penyerapan tenaga kerja di sekitar, akan tetapi keterlibatan pelaku industri dalam event-event yang ada di masyarakat masih belum terlihat.

Proses implementasi manajemen rantai pasokan berkelanjutan didorong oleh pengembangan industry wisata di Jogjakarta. Kebijakan ini berdampak pada terbukanya pasar dan konsumen baru untuk produk konveksi yang ujungnya adalah kenaikan permintaan 
akan produk. Disamping itu faktor kedekatan dengan lokasi pasar, tingkat persaingan yang meningkat, juga menjadi faktor pendukung laiinya, yang mendorong industry konveksi di daerah ini bisa berkembang dengan pesat.

Kondisi tersebut tentu saja memberikan dampak positif terhadap pencapaian keunggulan kompetitif. Seperti dijelaskan di bab sebelumnya, bahwa keunggulan kompetititf dalam penelitian ini diukur menggunakan lima indikator, yaitu harga, kualitas, inovasi produk, time to market, dan delivery dependability, Sebagai dampak penerapan manajemen rantai pasokan berkelanjutan, industry konveksi di daerah ini mampu mencapai keunggulan kompetitif berupa keunggulan harga, kualitas produk, dan delivery dependability dibanding produk konveksi sejenis yang dijual di daerah wisata Jogjakarta. Sementara indikator inovasi produk dan time to market masih belum mencapai tingkat keunggulan kompetitif di banding pesaing.

Selain faktor pendorong, tentu saja implementasi manajemen rantai pasokan ini terkadang juga mengalami kendala dan hambatan di lapangan, Dominasi peran supplier dalam menentukan harga, persaingan yang tidak sehat di antara pelaku industry, dan pengetahuan bisnis yang masih minim, sering menjadi masalah yang menghambat implementasi manajemen rantai pasokan berkelanjutan.

\section{Kesimpulan}

Manajemen rantai pasokan adalah sebuah system yang dibangun oleh perusahaan dalam menjalin hubungan bisnis yang saling menguntungkan diantara pelakunya. Industri konveksi di daerah Mlangi Sawahan Nogotirto adalah salah satu kelompok industry yang sudah berhasil mengimplementasikan proses ini. Meskipun para pelakunya tidak memiliki pengetahuan yang memadai, tetapi mereka sadar bahwa untuk mempertahankan keberlangsungan usahanya, mereka harus bekerja sama satu sama lain membentuk jaringan usaha untuk maju bersama-sama. Pola manajemen rantai pasokan di daerah ini sudah melibatkan supplier utama, supplier perantara, industry itu sendiri, pedagang besar dan eceran, serta konsumen akhir. Masing-masing tentu memiliki peran tersendiri dalam membesarkan usaha industry konveksi ini bersama-sama.

Implementasi

manajemen rantai pasokannya juga sudah terintegrasi dengan baik dan mendukung manajemen rantai pasokan berkelanjutan. Kondisi ini tentu saja memberikan dampak pada keunggulan kompetitif yang dicapai oleh industry, dibanding dengan pelaku industry sejenis di daerah Jogjakarta. Keterbatasan penelitian ini terkait dengan waktu penelitian yang singkat, sehingga peneliti hanya mampu mengkover sampel sebanyak 10 informan kunci. Akan tetapi meskipun hanya menggunakan 10 informan, informasi yang dihasilkan dalam penelitian ini dianggap cukup untuk menjawab pertanyaan penelitian, Riset ke depan, akan tetapi lebih bagus jika penelitian bisa diarahkan untuk pengambilan sampel yang lebih banyak sehingga informasi terkait dengan implementasi manajemen rantai pasokan di industry bisa lebih lengkap. Di samping itu Penelitian ke depan bisa difokuskan pada penelitian untuk mengukur kinerjamanajemen rantai pasokan berkelanjutan yang sudah dipraktekkan oleh industri.Penelitian ke depan juga bisa difokuskanpada hubungan industri dan konsumen, termasuk penilaian konsumen akhir terhadap produk konveksi yang dibeli

\section{Daftar Pustaka}

[1] K. Widodo, D. K. Pramudya and A. Abdullah, "Sistem Dinamis Industri Furnitur Indonesia Dari Perspektif Supply Chain Management Yang Berkelanjutan," Agritech, vol. 30 (2), 2010.

[2] W. J. Stevenson, Operation Management, New York: McGraw-Hill Wid, 2002.

[3] L. Rahmawati, "Pengaruh Supply Chain Management Terhadap Kinerja Dan Keunggulan Bersaing (Studi Kasus Pa)da Industri Kreatif Di Provinsi Jawa Tengah," Informatika, vol. 2 (3), pp. 89 - 103, 2011.

[4] M. Hisjam, "Perkembangan Riset Bidang Manajemen Rantai Pasok Berkelanjutan," Performa : Media Ilmiah Teknik Industri, vol. 17(2), pp. 103-110, 2018.

[5] S. Batubara, M. S. Maarif, M. and H. E. Irianto, "Model Manajemen Rantai Pasok Industri Perikanan Tangkap Berkelanjutan Di propinsi Maluku," Marine Fisherier, 
MATRIK: Jurnal Manajemen \& Teknik Industri - Produksi Volume XXII, No.1, September 2021, Halaman 85- 94

vol. 8 (2), 2017.

[6] Maisaroh, "AnalisisStrategi Usaha Sebagai Upaya Meningkatkan Daya Saing Usaha UMKM Sentra Industri Konveksi Di Sawahan Dan Mlangi Nogotirto Sleman," in Forum Manajemen Indonesia, Palembang, 2018.

[7] S. Assauri, Manajemen Produksi dan Operasi, Jakarta: Lembaga Penerbit UI, 2011.

[8] S. Russsel and T. W. Bernanrd, Operation Management 4th Edition, Pearson Education International, 2009.

[9] M. Harland, "Supply Chain Management : Relationships, Chains, And Networks," British Journal Of Managements, vol. 7, p. 63, 1996.

[10] Marimin and N. Maghfiroh, Teknik dan Analisis Pengambilan keputusan Fuzzy Dalam Manajemen Rantai Pasok, Bogor: IPB Press, 2013.

[11] L. Li, Supply Chain Management : Concept, Techniques, and Practices Enhacing Value Through Collaboration, Singapure: World Scientific Publishing Co. Pte. Ltd, 2007.

[12] J. Heizer and B. Render, Operations MAnagement 8th edition, US: Pearson education, Inc, 2006.

[13] T. Frochlich and R. Wstbrook, "Arch Of Integration : An International Study Of Supply Chain Strategies," Journal of Operation Mangement, vol. 19 (3), pp. 185-200, 2001.

[14] R. Narasimhan and D. Ajay, "The Impact Of Purchasing Integration And Practices On Manufacturing Performance," Journal Of Operation Management, vol. 19, pp. 593-609, 2001.

[15] S. Li, B. Ragu-Nathan, S. T. Ragu-Nathan and S. R. Subba, "The Impact Of Supply Chain Management Practice On Competitive Advantage And Organization Performance," Omega, vol. 34(1), pp. 107120, 2006.

[16] A. Gunasekaran, C. Patel and E. Titiroghi, "Performance Measuresand Matriccs In A Supply Chain Environment," International Journal Of Operations and Production, vol. 21, pp. 71-87, 001.

[17] M. Monszka, J. K. Petersen, B. R. Handfield and L. G. Ragetz, "Success
p-ISSN: 1693-5128, e-ISSN : 2621-8933 doi: $10.350587 /$ Matrik v22i1.2382

Factors In Strategic Supplier Alliences : The Buying Company Perspective," Decision Science, vol. 29, 1998.

[18] S. Seuring, "A Review Of Modelling ApproachesFor Sustainable Supply Chain Management," Decision Support Systems, vol. 54 (\$), pp. 1513-1520, 2013.

[19] P. Ahi and C. Ceurcy, "A Comparative Literature Analysis Of Definition For Green Sustanaible Supply Chain Management," Journal Of Cleaner Productive, vol. 52, pp. 329-341, 2013.

[20] M. E. Porter, Keunggulan Bersaing Menciptakan Dan Mempertahankan Kinerja Unggul, Jakarta: Erlangga, 1993.

[21] P. Kotler and G. Amstrong, Dasar-Dasar Pemasaran Jilid 1 Edisi Ke-9, Jakarta: Indeks Kelompok Gramedia, 2003.

[22] R. Kaplinsky and M. Morris, A Handbook For Value Chain Research, Brighton (UK): Institute Of Development Studies, University Of Sussex, 2001.

[23] (ACIAR) Australian Centre for Agriculture Research, "Membuat Rantai Nilai Lebih Berpihak Pada Kaum Miskin (Seri Terjemah)," Australian Centre for Agriculture Research, 2013.

[24] G. Gereffi, J. Humphrey and T. Sturgeon, "The Governance Of Global Value Chain," Review Of International Political Economy, vol. 12(1), pp. 78-104, 2005.

[25] R. Indrajit and R. Djokopranoto, Konsep Manajemen Supply Chain edisi Pertama, Jakarta: PT Grasindo, 2002.

[26] Maisaroh, "Kajian Karakteristik Kewirausahaan Terhadap Keberhasilan Usaha (Studi Kasus Sentra Industri Konveksi Dusun Mlangi Sawahan Nogotirto Gamping Sleman Yogyakarta," JUrnal Ekonomi, Bisnis, dan Akuntansi, vol. 21 92), 2019. 
(Halaman ini sengaja dikosongkan) 